\title{
CD56 for Multiple Myeloma: Lack of CD56 May Be Associated with Worse Prognosis
}

\author{
Kanji Miyazaki Kenshi Suzuki \\ Department of Hematology, Japanese Red Cross Medical Center, Tokyo, Japan
}

CD56, a neural cell adhesion molecule (NCAM), is a membrane glycoprotein of the immunoglobulin superfamily [1]. Although normal plasma cells do not express CD56, it is expressed by malignant plasma cells in approximately $65-80 \%$ of patients with multiple myeloma (MM) [2] and may be associated with osteolysis and a good prognosis. Furthermore, CD56 negativity may be associated with a poor prognosis, extramedullary involvement, plasmablastic morphology, a plasma-cell leukemic state, and nonhyperdiploidy chromosomal abnormality. However, these findings are debatable, and a previous study reported that patients with CD56-negative MM exhibited a lower frequency of osteolysis but were not associated with a poor prognosis [3].

In the last issue of Acta Haematologica, Skerget et al. [4] reported that a lack of CD56 is associated with worse progression-free survival in patients with R-ISS stage 2 MM treated by a bortezomib-based regimen, but not with worse overall survival. Although their results corroborated the results of previous studies, patients with R-ISS stage 2 comprise approximately $60 \%$ of MM patients and, in their study, the patient group was further stratified by CD56 expression [5]. They highlighted that a lack of CD56 expression remains one of the leading prognostic markers and that this should be tested when bone marrow is examined, even when bortezomib or other treatments are used.

In our practice, CD56 is regularly assessed by using flow cytometry and immunohistochemistry, along with other markers, when we examine the bone marrow samples of patients with plasma-cell dyscrasia [6]. We consider CD56 as one of the essential markers for patients with MM. In the era of monoclonal antibodies, the downregulation of CD38 or CD138 is often observed, and other markers, such as CD56 and cyclin D1, have become relatively significant.

In conclusion, CD56 may indeed be associated with prognosis and remains one of the leading myeloma markers, as Skerget et al. [4] reported. We recommend assessing CD56 as well as other myeloma markers in the clinical practice setting.

\section{KARGER}

(c) 2018 S. Karger AG, Basel

E-Mail karger@karger.com

www.karger.com/aha
Kenshi Suzuki, MD, PhD 


\section{References}

1 Cunningham BA, Hemperly JJ, Murray BA, Prediger EA, Brackenbury R, Edelman GM: Neural cell adhesion molecule: structure, immunoglobulin-like domains, cell surface modulation, and alternative RNA splicing. Science 1987;236:799-806.

2 Van Camp B, Durie BG, Spier C, De Waele M, Van Riet I, Vela E, et al: Plasma cells in multiple myeloma express a natural killer cellassociated antigen: CD56 (NKH-1; Leu-19). Blood 1990;76:377-382.
3 Kraj M, Sokolowska U, Kopec-Szlezak J, Poglod R, Kruk B, Wozniak J, Szpila T: Clinicopathological correlates of plasma cell CD56 (NCAM) expression in multiple myeloma. Leuk Lymphoma 2008;49:298-305.

4 Skerget M, Skopec B, Zadnik V, Zontar D, Podgornik H, Rebersek K, Furlan T, Cernelc $\mathrm{P}$ : CD56 expression is an important prognostic factor in multiple myeloma even with bor tezomib induction. Acta Haematol 2018, DOI: $10.1159 / 000489483$.
5 Palumbo A, Avet-Loiseau H, Oliva S, Lokhorst HM, Goldschmidt H, Rosinol L, et al: Revised International Staging System for Multiple Myeloma: a report from International Myeloma Working Group. J Clin Oncol 2015;33:2863-2869.

6 Miyazaki K, Suzuki K: Clinical and laboratory significance of CD56 (a neural cell adhesion 380 molecule) positivity in multiple myeloma and AL amyloidosis. Int J Myeloma 2015;5: 30-35. 